\title{
アミン類を主剤とする防蝕剤の研究（III）
}

\author{
助剤としての酸について
}

\author{
藤井晴一*・荒牧国次* 一上原一郎米
}

\section{Studies on Amine Type Corrosion Inhibitors (3rd Report)}

Acids as Subsidiary Components of Amine-Inhibitors

Seiichi Fujii, Kunitsugu Aramaki \& Ichiro Uehara

Among hexadecylamines-inhibitors (or octadecyla mines) effective ones could be found when they were made by reacting $1 \mathrm{~mol}$. of amines with 2 or 3 mols. of acids. We have tested various corrosion inhibitors.

\section{[1]}

前二報に尔いて，高級脂肪族アミン特に $\mathrm{C}_{16}$ むょよび

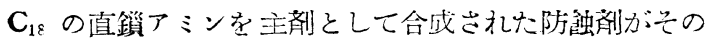
使用量に心差異が認められるが，多るい!性，アルカ リ性の海水中，㤁るいは強酸中の如き $\mathrm{pH}$ の広い範䎳て

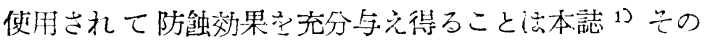
他 2) 報告を行つ元。従来インヒビターとして使用さ

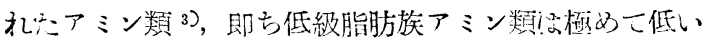

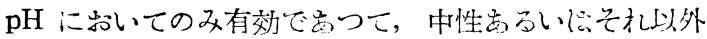
の $\mathrm{pH}$ の水溶液中では效果を上げ得ないものとなされて いるのに対して高級アミンに岕いてはか子る欠点を有し ない点で興味を持たれるから本報告にむいてていすへて人

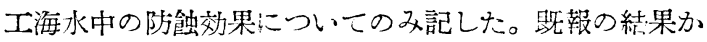

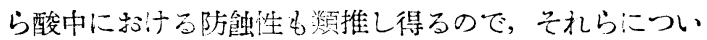
ては割愛したものでらる。高級脂肪族アミンは跃報のご とく若干の酸を反応さしめることによりその防強性を更 に増大せしめ得るが，本研究によつてその助用とな寸酸 のアミンーインヒビターの防強性に及代す一般的傾问を 論じようと思う。なむ本報告に使用されたアミンはす ベこ n-hexadecylamine でぁり，所要の酸とともに約 $100^{\circ} \mathrm{C} に 0.5 \sim 1$ 時間加熱反応させてインヒビターと した。

実験においてはインヒビターば若干の溶绪〔主として 覀麻仁油)に溶解せしぬ同時に乳化肪(主として中性洗 成)を添加して人工海水 ${ }^{4}$ 中の乳化も可及的に良好な らしめ，軟鋼テストピースを室温，開放で沂定の時間 (48〜100 時間) その液中に浸漬しその減量から浸蝕率 both in sea water and in acidic solution, which consist of $n$-hexadecylamines and various fatty acids. When those were $\mathrm{C}_{8}-\mathrm{C}_{12}$ straight chain acids or unsaturated $\mathrm{C}_{18}$ ones, best inhibition could be expected.

を求めたものである。一般に実験結果は各々の間の明確 なる差異を得儿としたために，かなり苻酷な条件で奏験 したものでかるから, 必ずしも最上の防強効果を期待し たものと一致しない埸合电克る。

[2]

跣報の如く 1 モルの高級アミンと 2 3 モルの不飽和 脂肪酸との混合溶融物!極めて有効なインヒビタ一でる るが， その構造法未だ確定的に結論を下し得ない。しか し日下゙のところ次の如き反応機構が妥当と考只ている。 即方

$$
\begin{aligned}
\mathrm{R} \cdot \mathrm{NH}_{2} \stackrel{\mathrm{R}^{\prime} \mathrm{COOH}}{-}-\mathrm{H}_{2} \mathrm{O} & \rightarrow \mathrm{R} \cdot \mathrm{NH}\left(\mathrm{COR}^{\prime}\right) \\
& \stackrel{\mathrm{R}^{\prime} \mathrm{COOH}}{-} \rightarrow \mathrm{H} \cdot \mathrm{N}\left(\mathrm{H}_{2} \mathrm{O}\right.
\end{aligned}
$$

さらに溶液中心たに㗭濁液中で $\mathrm{N}$ 一原子に1モルの酸 $\mathrm{HX}$ 分附加して, 各々

$\left[\mathrm{R} \cdot \mathrm{NH}_{3}\right]^{+} \mathrm{X}^{-},\left[\mathrm{R} \cdot \mathrm{NH}_{2}(\mathrm{COR})\right]^{+} \mathrm{X}^{-}$,

$$
\left[\mathrm{R} \cdot \mathrm{NH}^{\prime}\left(\mathrm{COR}^{\prime}\right)_{2}\right]^{+} \mathrm{X}^{-}
$$

の如き式で表わし得ると考光得ら。

アミンと酸のモル比についこに最近㵎滑油に添加与る ラスト・インヒビターとして，1モルのアミンと 2〜4 モルの脂肪酸の区忘生成物を最良と古報告 5 力 が Zisman により行わ机， その反空㙨嬿についてわ机われ

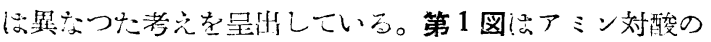
モル比を $1: 1,1: 2,1: 3,1: 4$ の如く変えてそ机ぞ礼イ ンヒビターを作りそのインヒビターの一定の濃变に效け る防蝕効果をしらべたもので志るが，モル比 1:3にむ いて最良で品る。またインヒビター中のアミンが一定濃

* 慶応大学工学部 $* *$ 帝国石油株式会社 
度になるよう添加したときもアミン1 モルに対し 3〜4 モルの肪脂酸の忠る場合において最良の結果に達した。 これよりアミン 1 モルに対し脂肪酸が 3 モル出るときに

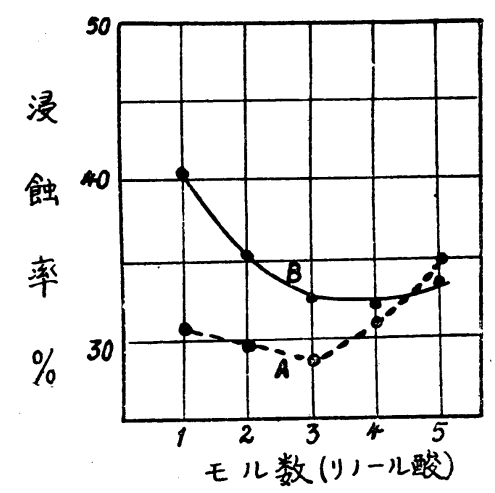

第 1 図 $\mathrm{n}$-Hexadecylamine-Linoleic acid Inhibitor による效果

条件: A. 20 p. p.m. B. $1.5 \times 10^{-5} \mathrm{~N}-\mathrm{mol} / \mathrm{lit}$ 窒温 $96 \mathrm{hrs}$

インヒビターとして最も良く, 防蝕効果からも前式を主 張したので出るが，Kaufman 等 ${ }^{62}$ によると非極性溶媒 のベンゼン中にアミンと脂肪酸の共存する場合, 间者は 会合していると考え，ベンゼンの如き非極性溶媒中でる アミンが極性化しているとしている。しかし潤滑油中の

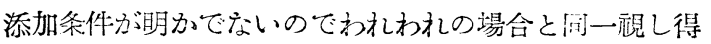
るかは疑間である。しかし定性的奏験で号出るが，われ われの縮合物も塗料の如き有機溶媒中でなおインヒビタ ーとしての機能を有小ることは証し得た。

\section{[3]}

アミン・インヒビター中のアミンの有する $\mathrm{N}$ 一原子は 正電荷を有していると考えられる。これらの極性化を助 ける酸な有機酸無機酸を問わない。前報において塩酸お

第 1 表 Inhibitor: $\left[\mathrm{C}_{16} \mathrm{H}_{33} \mathrm{NH}_{3}\right]^{+} \mathrm{X}^{-}$

\begin{tabular}{|c|r|r|}
\hline 酸 & 浸玲率 $\mathrm{mm} / \mathrm{yr}$ & 浸 刢 率 \% \\
\hline ブ ラ ン & 0.0636 & - \\
\hline $\mathrm{HCl}$ & 0.0110 & 17.8 \\
\hline $\mathrm{HNO}_{3}$ & 0.0106 & 16.7 \\
\hline $\mathrm{H}_{3} \mathrm{PO}_{4}$ & 0.0110 & 17.8 \\
\hline
\end{tabular}

条件: 20p.p.m. 温空 90hrs.

よび醮酸塩等につき必要なことのみ多少述べておいたの であるが，本論文にむいていこれらの闍題を主として論 じてゆきたい。苐 1 表に示したものは単にアミン塩を溶 用の亜麻仁油に溶かして使用した結果を示するのであ る。インヒビターの使用量としてはアミン単体として 20

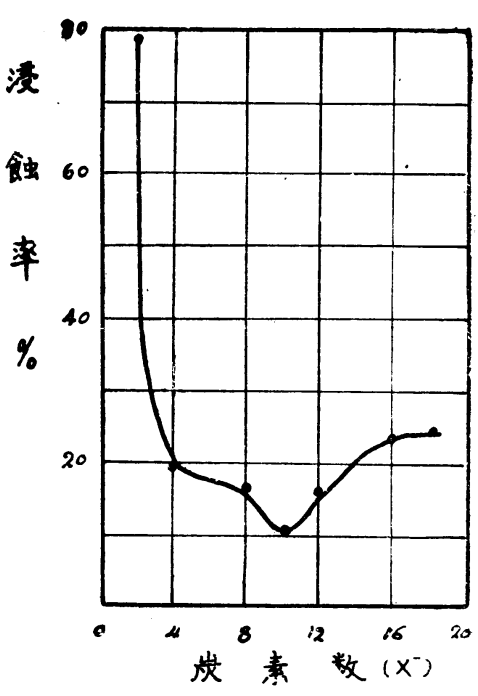

第 2 図 Inhibitor: $\left[\mathrm{C}_{16} \mathrm{H}_{33} \mathrm{NH}_{3}\right]^{+} \mathrm{X}^{-}$による変化 条件: 20p.p.m 室温 $90 \mathrm{hrs}$

p.p.m になるようにした。従つて常に同一量のアミンが 㦄触液中に存在するようにしたものでらる。

鉱酸でアミン塩を作る場合として $\mathrm{HCl}, \mathrm{HNO}_{3}, \mathrm{H}_{3} \mathrm{PO}$ について奏験を行つたがいずれる同程度の防蝕率を示し ている。これらインヒビターは自体乳化分散性を有する が，概して有機酸塩と異り被膜性に乏しい。従つてアミ ンの無機酸塩!有機酸塩と異り水中への分散と金属表面 への被膜を不断繰返していると焽われる。彷つてこれら の塩の防強状態低級脂肪酸のアミン塩の如き薄い、被膜 を作つている。又これら溶剤との構造上の著しい懸隔 のために金蚎表面に配位したた後更に西麻仁油を引きつけ る機能に欠けているためかとも考方られる。

有機酸については $\mathrm{C}_{2}$ 醮酸より $\mathrm{C}_{18}$ ステアリン酸に至 る偶数の㟶素数を有する脂肪酸の塩孛用いた結果でるる が，(第2図)酰酸塩で処理した防赨液中に心錆が沈澱 やず一見完全防蝕の如くで圭るが，腐玲減量からは最も 恶い。广なわち鉄は液中に溶解している。又防蝕効果の 上る一因である乳化性についてに $\mathrm{C}_{4} \sim \mathrm{C}_{12}$ の酸の塩が艮 く，厹狄上上酸の塩で良くない。この点から $\mathrm{C}_{10}$ の 酸のアミン塩がテストビースの減量よりする防蝕性で最 高を示古原因と考えされる。捡言す狄ば，これいは $\mathrm{C}_{16}$ の

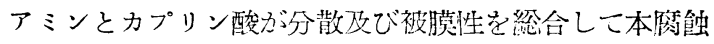
液では最も適与る塩を作るためと考穴られる。

\section{[4]}

本アミンインヒビターで前記の如く 3 モルの酸を用い たインヒビターが最良の結果であるから第1モル，第 2 モル目の酸としてリノール酸它用いて $\mathrm{C}_{16}$ アミンと充分 高温で混合し，これを第 3 モル目の酸として諸種の酸と 
再で混じてインヒビターとなし実験した結果を次に示す

第 2 哀 Inhibitor: $\left[\mathrm{C}_{16} \mathrm{H}_{33} \mathrm{NH}\left(\mathrm{COC}_{17} \mathrm{H}_{31}\right)_{2}\right]^{+} \mathrm{X}^{-}$

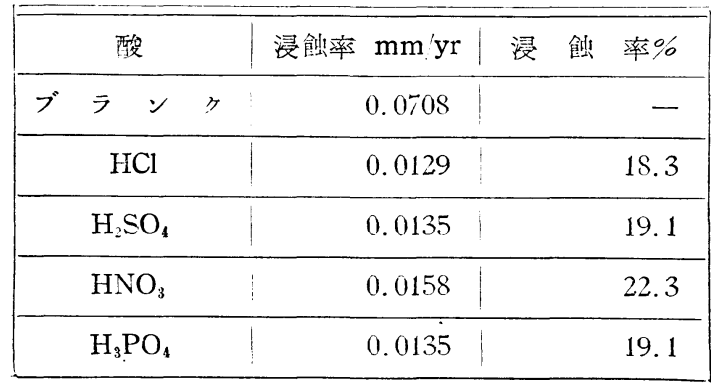

条件: 20p.p.m. 宝温 $72 \mathrm{hrs}$.

即ち，第3モル日の酸として無嘰酸により処理した場

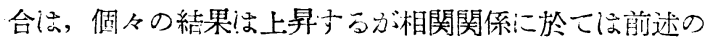
アミン塩と同様つ紨果で占る。又テストピース面に吸着

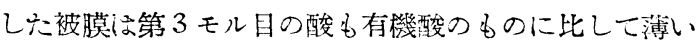
ように思市礼ら。

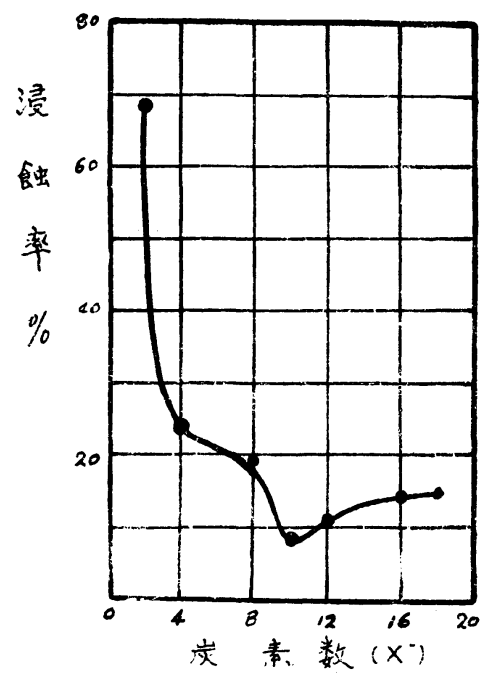

第3図第3モル日を有栧酸とせる変化 nhibitor : $\left[\mathrm{C}_{16} \mathrm{H}_{33} \mathrm{NH}\left(\mathrm{COC} ; \mathrm{H}_{31}\right)_{2}\right]^{+}[\mathrm{RCOO}]^{-}$ 条件: p.p.m. 室温 76 kes.

ふモル日に有機酸を用いて抑制削となぜる場合につい ては，アミン塩と大体问様の傾问条示才ので出るが，全 般的に高級の肪脂酸が良い傾向に傾いて来る。これいか第 1 第2 モル目のリノール酸によつて比較的分散性の良い インヒビターを作るさめと思市机る。

アミンの誘導体で出るインヒビターは訪諸種の酸によつ

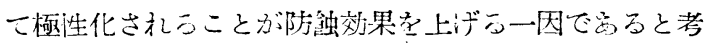
える分，この㥛性化は一般こアミン塩として与えられる

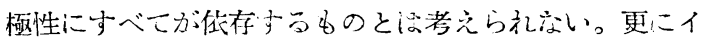
ンヒビター分子の立体㮖造或心金属表面への吸着機潇に もよるものでるる5が，第了モル目の酸子前美験と同じ

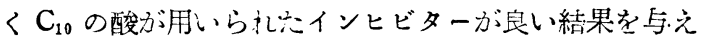
る点は興味のむることであろう。

\section{[5]}

以上の如き第 3 モル目の酸の傾向は脂肪酸では第 1 及 び第2モル目の酸についても同じく考えられる。然しな がら一般に脂肪酸は宸素数が 5 6 沦の低級脂肪酸とそ れ以上の高級脂肪酸とが相当諸性質を異にするので问一 に取扱うのは早計にすぎるか子知れないが，比較のため に $\mathrm{C}_{2}$ 酶酸より $\mathrm{C}_{18}$ ステアリン酸に至る種々の孷素数の 偶数の飽和脂肪酸の 3 モル混合溶融物について防蝕試験 を試多た。その結果，ほ心゙上述の〔4]およで〔5]の 試験と類似, 関係它得た。(第4図) $\mathrm{C}_{8} \sim \mathrm{C}_{12}$ 間, 特に $\mathrm{C}_{1}$ の炭素数の脂肪酸が最子優秀なる結果を与えた。これ等 は乳化分散性に於いてすぐれている。 $\mathrm{C}_{12}$ ラウリン酸以 上の高級脂肪酸がインヒビターの助郕として用いられた 時インヒビターの融点を高くし溶绪にば相当不溶でま

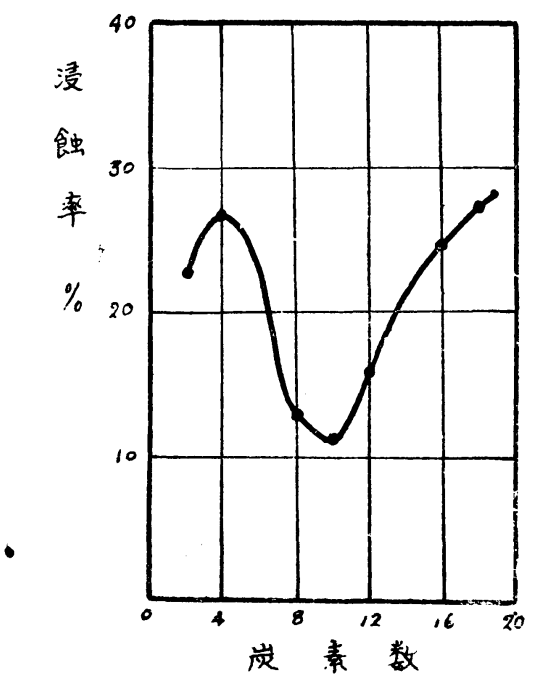

助剂としてひ有峨酸による変化

第 4 図 Inhibitor : $\left[\mathrm{C}_{16} \mathrm{H}_{33} \mathrm{NH}(\mathrm{COR})_{2}\right]^{+}[\mathrm{RCOO}]^{-}$ 条件: 20p.p.m 室温 $72 \mathrm{hrs}$.

る。従つこ分散性が西くなら久点がある。然し分散粒子 の大きさゔ影響を有すると考えら被膜は泊状に厚く形成 される。特に乳化或な分散を必亚としない場合，例之ば 比較的易溶な塗料潤滑油等の場合或!温度の高い場合等 には効果索上げるのでなないかと思われる。

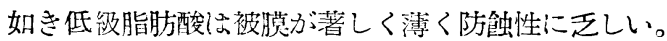

\section{[6]}

$\mathrm{C}_{15}$ のアミンと $\mathrm{C}_{10}$ の脂肪酸との縮合物が防玲性が最 女良い結果希与える事は先に示した如くである。而して 此等の良い原因としてインヒビターの融点の比較的低い 事, 或に使用する酸の親水基, 親油基のバランスの問題 等を考它伷せると不䬣和脂肪酸若くは不飽和オキシ脂肪 酸等を用うるならば $\mathrm{C}_{10}$ より更に崖素数の多いるの使 用し得る。比較的入手の簡単な $\mathrm{C}_{18}$ の夫等について更に 
実験を試みた。

不館和酸を助剤として使用した場合の一つの利点とし て, 二重綕合に依り溶存酸素を吸収して乾性油の如く酸 素橋を作り形成された皮膜を堅牢にすることが考えられ る。气の為に溶媒として此等の分散に依比較的不利で去 出るが，夫自作の效果のないベンゼンを使用し，不飽和 酸として上記の酸女でそれ等の中間の不飽和度の混合物 を用いた結果，第 5 図に示寸如くその倾向として二重結

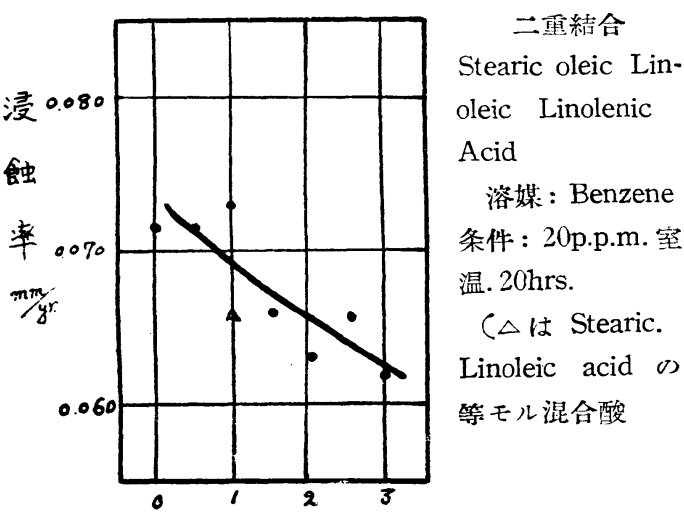

苐 5 図二重結合を助剤に与元たときの变化

合の増加が防蝕效果を堌大せしめる結果が得られた。

覀麻仁油を溶媒として種々の二重結合を持つ上記の酸 について実験を行つた綕果，明かに二重結合の增加によ り防蝕効果! 堌大している。且つ二種の酸の混合物を助 郕としたインヒビターに於いてもそれ等の順当なる効果 を示している。この様な一様な関係を示している事は, 防 蝕能力が㑛水性皮膜をなすアルキル基に体存すると考穴 るならば，二重結合のために扢こる cis 及び trans の立

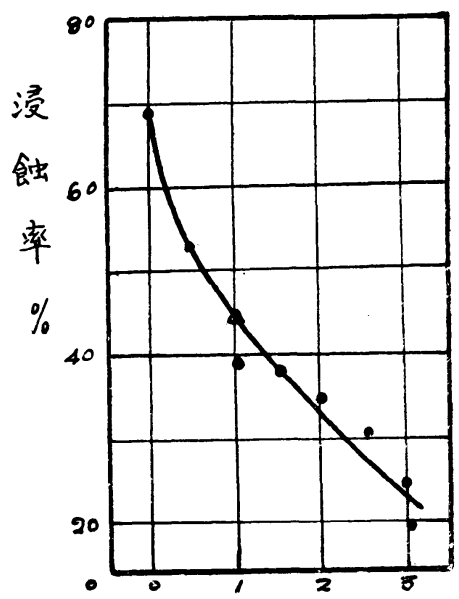

第6 図二重結合を助剂に与天溶媒亞麻仁油用いたと きの变化溶媒：亞麻心油条件：20p.p.m. 室温 $72 \mathrm{hrs}$.

体巽性による美異が表われてもよい様汇思われるるが溶媒 の亜麻仁油を更に被膜上に引き付けているのて明かな差
を見せないのでむろう。この点に関しては更に乳化性の 良い $\mathrm{C}_{8}$ のアミンの縮合物のみで cis 及び trans の酸を 用いて比較を行いたい。又これ等不飽和酸によつて作ら れたインヒビターの有機化学的構造が抑制効果に影響を 叉ぼすか否かを検べるために，例えば二重結合一つのオ レイン酸の 3 モルを用うる代りに，ステアリン酸及び二 重結合 2 有寸るリノール酸を 1.5 モル宛混じた酸とア ミン1モルとを反応せしめた如きインヒビターを作つて 実験して見た。かくの如きインヒビターも筧に不飽和度 のみに関して化学構造が美違を示さなかつた。即も溶剤 の影響が之れにも表われ，鉄の表面に配位しホインヒビ タ一被膜の上に組織類似の两麻仁油の被膜を作らせて, 結局インヒビターの差が表われなからたと考えざるを得 ない。

以上の関係は不飽和度の増加アルキル基の㨂水性を或 る程度緩和し $\mathrm{N}$ 一原子の極性に釣合うこと，或は融点を 下げることより分散性を良くする事等が理由として考え られる。二重結合の増加が溶剤の亜麻仁油に適応するこ と滍明かで，ベンゼンを使用した場合より洎かに皮膜を 厚くし，好紶果者得ている。

第 3 表 Inhibitor : $\left[\mathrm{C}_{16} \mathrm{H}_{33} \mathrm{NH}(\mathrm{COR}){ }_{2}\right][\mathrm{RCOO}\rfloor-$

\begin{tabular}{|c|c|c|c|}
\hline 酸 & 浸飿率 $\mathrm{mm} / \mathrm{gr}$. & 防 領 & 率\% \\
\hline ブ ランク & 0.0632 & & - \\
\hline リシノレイン酸 & 0.00418 & & 93.4 \\
\hline 乳 & 0.0168 & & 73.5 \\
\hline
\end{tabular}

条件: 20p.p.m. 室温 96hrs.

更にアルキル基に親水基として水酸基支持つ酸索助用 として用いたインヒビターについて，その赛験を試み た。特にリシノレイン酸を用いる時に著しい防蝕性を認 めた。リシノレイン酸は二重結合と水酸基を持つが，こ の場合乳化性が非常に良く，アルキル基に親水基を与兄 る事が乳化分散性を良好とする結果，たとへ $\mathrm{C}_{18}$ の酸で も桠性を与える点て $\mathrm{C}_{10}$ と比肩し更に $\mathrm{C}_{18}$ の長鑥の效果が 防蛝間を延長せしめることになつたのでるなからうか

\section{[7]}

以上の如く腐蝕滅量の実験で諸酸学助戍とするインビ ターの防蝕傾向を知ることが出来たが，これらインヒビ ターに就いて次の如き電気化学的実験に於ても全く同じ 様な傾向を示している。即ち前述の実験に用いたインヒ ビターを用いて食塩水溶液中で同一面積を有する铁及び 銅極間を流れる雷流を第 7 図に示せる装置で測定した。 其の結果流前記実験と全く同じ順位が 4 時間後の電気の 電流量によつて決せられる事を知つた。即ち此等の実験

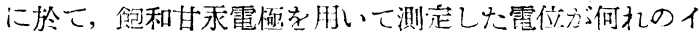
ンヒビターを入れて行つな测定でも㱠どその差異を認め 


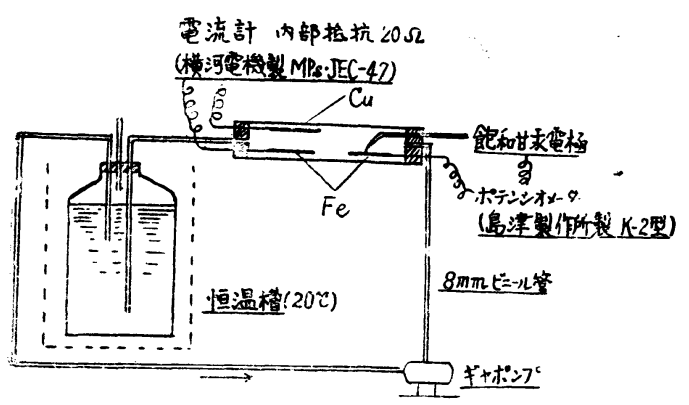

第 7 図 $3 \% \mathrm{NaCi} 5$ lit 流速: $5 \mathrm{~cm} / \mathrm{sec}$.

電気抵抗: $0.3854 \Omega \mathrm{m}\left(20^{\circ} \mathrm{C}\right)$

極面槕: $7.5 \mathrm{~cm}^{2}$, 極間 $: 2.5 \mathrm{~cm}$.

得ず，従つて雪流盟に多少のあることはインヒビターに 被膜さ机た地域の多少と相䦭々倸にあることを亦少子の であるとが判る。例之代助郕の飽和脂肪酸による差異

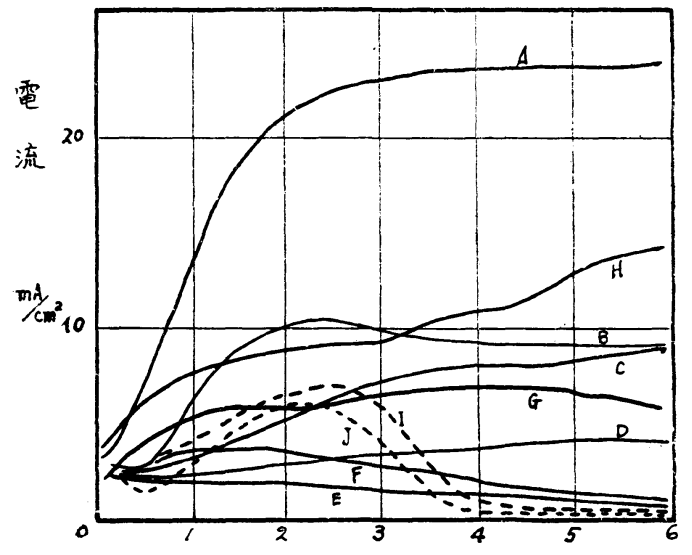

時 間 hrs.

第 8 図

Acid

$\begin{array}{ll}\text { A } & \text { Blank } \\ \text { B } & \text { acetic } \\ \text { C } & \text { butyric } \\ \text { D } & \text { caprylic } \\ \text { E } & \text { capric }\end{array}$

Inhibitor : $\left[\mathrm{C}_{16} \mathrm{H}_{33} \mathrm{NH}(\mathrm{COR})_{2}\right]+[\mathrm{RCOO}]^{-}$20p.p.m

による防蝕效果の差巽!常に本実験の差異と一致してい る。たよ゙不飽和脂肪酸が助剂である時に寒験の初期に括 いて，電流量の増大が見られている。この段階を経て電 流量は激減して 4 時間目以後で前实験結果と一致するの であつて，この点は明らかにインヒビターの立体構造上 から来る特性ではないかと考えられるもので，今後の研 究に興味を有与るものでるろう。たがこ〉の電気的测定 結果は開始より6時間の間の電流の変化のみをプロット したものであるから前記実験の如き長時間を経過せるも のの結果と直ちに一緒にして良いものか判らないが， 6 時間後にテストピースの腐蟲量き測定したものとも良く
一致した。たよ゙6時間位の腐蝕量はや〉すすると天科の 感度外で論ずる恐れのむるために，本記述中では省略す ることにした。

\section{[8]}

以上の結果から $\mathrm{n}$ 一hexadecylamine を主刜としたイ ンヒビターではこれに2ないし 3 モルの $\mathrm{C}_{8} \sim \mathrm{C}_{12}$ なか しづく $\mathrm{C}_{10}$ の飽和脂肪酸と加熱溶融したものが息く，低

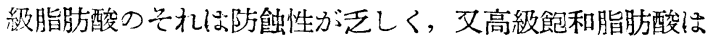

第 4 表 Inhibitor: $\left[\mathrm{C}_{16} \mathrm{H}_{33} \mathrm{NH}(\mathrm{COR})_{2}\right]^{+}[\mathrm{RCOO}]^{-}$

\begin{tabular}{|c|c|c|c|}
\hline 酸 & 漫飭率 mm/gr & 防 蝕 & 率兑 \\
\hline ブ ラ ソ ク & 0.0068 & & - \\
\hline カプリソ酸 & 0.00740 & & 89.1 \\
\hline リノレン酸 & 0.00808 & & 88.1 \\
\hline リシノレイン酸 & $0.0033 i$ & & 95.2 \\
\hline
\end{tabular}

条件: 20p.p.m. 室温 $72 \mathrm{hrs}$

分散性力゙悪い。然し高級脂肪酸も二重結合多るいは他の 親水基を持つことによりこの欠点を補う事が出来る。す なうち, 不飽和轵では二重結合の堌加と共に防蝕性は壇 大与る。以上の諸実駼から得られる最も效果のあるカプ リン酸，リノレン酸及びリシノレイン酸を助剤とするイ ンヒビターの同時実験の結果を第 3 表に示す。これによ れば，カプリン酸とリノレン酸はほが问程度の防蝕性を 有している。これい! 10 の㟶素数を有するカプリン酸と

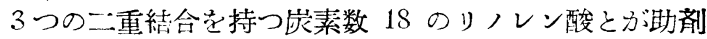
として大体问様な性質をインヒビターに与をることを示 している。二重結合及び水酸基を持つリシノレイン酸! 乳化性更で皮膜性にすぐれてている。

助戍としての酸については $\mathrm{C}_{16}$ のアミンでは上述の結 果でするが，アミンの鑟の長さ宓るい!第一級アミンの みでなく，第二級又は第三欲アミンにより更に影管さ受 けるであろう。幸に $\mathrm{C}_{8} \sim \mathrm{C}_{18}$ の諸アミン類についても研 究の緒についているので近く報告出来ると考えている。

\section{文献}

1) 藤升晴一：防㓩技術资料 1，No. 6,39(1952).

藤非晴一. 活较国次：防蝕技術資料，2，No.3, 230 (1953).

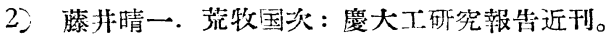

3) Mann, Lauror \& Multin: Ind. Eng. Chem. 28,59, 1048 (1936).

4) N.N. Suboro: Oceanographical Tables, p. 208 (1931) Moscow.

5) W. A. Zisman : Ind. Eng. Chem. 45, 1406 (1953).

6) S. Kaufman, C. R. Singleterry: J. Phys. Chem. 56, 604 (1952) 